УДК 342.9

DOI https:// doi.org/10.32850/LB2414-4207.2020.17.15

\title{
ПРИНЦИПИ ВІДКРИТТЯ ПРОВАДЖЕННЯ В АДМІНІСТРАТИВНІЙ СПРАВІ
}

\author{
Гебеш Сергій Антонійович, \\ суддя \\ (Закарпатський окружний \\ адміністративний суд, м. Ужгород, \\ Україна)
}

Стаття присвячена визначенню та розкриттю принципів відкриття провадження в адміністративній справі як стадії адміністративного судочинства, адже правильно встановлений зміст і обсяг принципів всіх стадій процесу дає широкі можливості для розвитку адміністративно-процесуальних правовідносин.

Автор, аналізуючи наукову літературу та законодавство України 3 адміністративного судочинства, дійшов висновку про те, що раніше не проводилося дослідження щодо визначення принципів окремих стадій адміністративного процесу.

У статті комплексно розкриваються загальноправові принципи, на яких заснований весь адміністративний судовий процес (верховенство права, законність, гласність і відкритість судового процесу та його повне фіксування технічними засобами, обов'язковість судового рішення, забезпечення права на апеляційний перегляд справи, забезпечення права на касаційне оскарження судового рішення у випадках, визначених законом).

Доведено, що стадія відкриття провадження має притаманні тільки їй правові принципи, на підставі додержання яких стає можливим ефективне здійснення всіх процесуальних дій судді на певній стадії. До таких спеціальних принципів автор відносить дотримання строків, встановлених для відкриття провадження, обов' язковість розгляду позовної заяви на відповідність встановленим законом вимогам і вжиття всіх необхідних дій щодо ії перевірки, принцип забезпечення доступу до суду.

У висновках до статті констатується, що вирішення проблеми теоретичного дослідження принципів цієї стадії набуває особливого значення з огляду на важливість забезпечення кожного правом на справедливий судовий розгляд на всіх стадіях адміністративного судочинства.

Ключові слова: принципи, відкриття провадження, адміністративна справа, адміністративне судочинство.

\section{PRINCIPLES OF INITIATION OF ADMINISTRATIVE PROCEEDINGS}

\author{
Hebesh Serhii Antoniiovych, \\ Judge \\ (Transcarpathian District Administrative \\ Court, Uzhhorod, Ukraine)
}

The article is devoted to defining and disclosing the principles of initiating proceedings in an administrative case as a stage of administrative proceedings, because the correctly established content and scope of the principles of all stages of the process provides ample opportunities for the development of administrative procedure. 
Analyzing the scientific literature and legislation of Ukraine on administrative proceedings, the author came to the conclusion that previously no study was conducted to determine the principles of individual stages of the administrative process.

The article comprehensively reveals the scientific opinion on the general legal principles on which the entire administrative judicial process is based (rule of law, legality, publicity and openness of the judicial process and its full fixation by technical means, binding court decision, ensuring the right to appeal, securing the right on cassation appeal of a court decision in cases specified by law).

It is proved that the stage of initiating proceedings has its own legal principles, on the basis of which it becomes possible to effectively carry out all procedural actions of a judge at this stage. Such special principles include the author's compliance with the deadlines set for the opening of proceedings, the obligation to consider the statement of claim for compliance with statutory requirements and take all necessary steps to verify it, the principle of access to court.

The conclusions to the article state that the solution of the problem of theoretical study of the principles of this stage is of particular importance given the importance of ensuring everyone the right to a fair trial at all stages of administrative proceedings.

Key words: principles, initiation of proceedings, administrative case, administrative proceedings.

Актуальність теми. Відображаючись у нормах права, принципи адміністративного судочинства характеризують не тільки суть, а й зміст адміністративного судочинства, характеризують не тільки його внутрішню побудову, а і весь його процес. Правильно встановлений зміст і обсяг принципів всіх стадій процесу дає широкі можливості для розвитку адміністративно-процесуальних правовідносин. Відкриття провадження в адміністративному судочинстві має власні завдання, котрі визначають характер дій і специфіку застосування на цій стадії правових засобів для забезпечення реалізації права на судовий захист. Таке застосування має грунтуватися на певних правових засадах, які відображають внутрішню суть стадії відкриття провадження у справі адміністративного судочинства. Саме тому вирішення проблеми теоретичного дослідження принципів цієї стадії набуває особливого значення з огляду на важливість забезпечення кожного правом на справедливий судовий розгляд на всіх стадіях адміністративного судочинства.

Постановка проблеми. Аналіз наукової літератури та законодавства Україниз адміністративного судочинства показав, що раніше не проводилося дослідження щодо визначення принципів окремих стадій адміністративного процесу. Панує думка, що загальновстановлені принципи судочинства пронизують весь судовий процес, а тому логічно, що його стадії мають грунтуватися на законодавчо встановлених засадах судової діяльності. Натомість загальновизначені принципи, попри їхнє значення для справедливого розгляду справи по суті, не можуть бути застосовані на всіх стадіях судочинства, оскільки «стадія є порівняно самостійною частиною провадження, яка поряд із його загальними завданнями має властиві тільки їй завдання, документи та інші особливості» [1, с. 155-156]. У свою чергу, кожен принцип правосуддя виконує власну, чітко визначену роль в організації та діяльності адміністративних судів [2, с. 176]. Це яскраво підтверджує той факт, що кожна окрема стадія адміністративного судочинства базується як на принципах адміністративного судочинства взагалі, так і на принципах, які ії характеризують як стадію $з$ певними завданнями та як сукупність процесуальних дій. Слушною з цього приводу є думка С.В. Ківалова, котрий зазначає, що «принципи є тісно взаємопов' язаними і становлять у сукупності систему, 
кожен із принципів відіграє самостійну роль, характеризує адміністративне судочинство загалом або ж окрему стадію адміністративного судового процесу» [3, с. 5].

Мета статті полягає в усуненні наукової прогалини щодо визначення сутності, значення та переліку принципів відкриття провадження у справі як стадії адміністративного судочинства. Задля досягнення поставленої мети в роботі передбачається: 1) визначити й охарактеризувати загальні принципи адміністративного судочинства, які одночасно є принципами відкриття провадження в адміністративній справі; 2) виокремити та розкрити спеціальні принципи відкриття провадження як стадії адміністративного судочинства.

Виклад основного матеріалу. Аналіз законодавства 3 адміністративного судочинства й аналіз наукових теоретичних розробок дозволяє нам виділити принципи відкриття провадження у справі та поділити їх на загальні, на яких заснований весь адміністративний судовий процес, і на спеціальні, на яких заснована сукупність процесуальних дій судді безпосередньо на стадії відкриття провадження.

Розглянемо спочатку загальні принципи. Виокремимо серед усієї сукупності таких загальних принципів ті, які, на нашу думку, мають важливе теоретичне значення: 1) верховенство права; 2) законність; 3) гласність і відкритість судового процесу та його повне фіксування технічними засобами; 4) обов' язковість судового рішення; 5) забезпечення права на апеляційний перегляд справи; 6) забезпечення права на касаційне оскарження судового рішення у випадках, визначених законом.

Принцип верховенства права є загальним і притаманний всім видам діяльності у сфері реалізації державної влади. Він прямо закріплений у ст. 8 Конституції України, де зазначено, що в Україні визнається і діє принцип верховенства права. Конституція України має найвищу юридичну силу. Закони та інші нормативно-правові акти приймаються на основі Конституції України та повинні відповідати їй. Норми Конституції України є нормами прямої дії. Звернення до суду для захисту конституційних прав і свобод людини та громадянина безпосередньо на підставі Конституції України гарантується [4]. Отже, цей принцип визначає зміст і спрямованість діяльності судової гілки влади, однак, на думку О. Корчинського, «має особливе значення саме для адміністративного судочинства, оскільки предметом розгляду в адміністративних судах часто є правові акти, які прийняли органи влади стосовно громадян» [5, с. 153]. На важливість цього принципу для адміністративного судочинства вказує також і М.В. Ковалів. «Його правильне застосування залежить від рівня правової підготовки, правової свідомості, правової культури кожного судді адміністративних судів. Застосування принципу верховенства права під час здійснення адміністративного судочинства дозволить забезпечити належний захист прав, свобод та інтересів фізичних осіб, прав та інтересів юридичних осіб у сфері публічно-правових відносин від порушень із боку органів державної влади, органів місцевого самоврядування, їхніх посадових і службових осіб, інших суб'єктів у здійсненні ними владних управлінських функцій на основі законодавства, зокрема на виконання делегованих повноважень» $[2$, с. 176].

На стадії відкриття провадження сутність верховенства права полягає у тому, що суд не повинен при перевірці позовної заяви на предмет іiі обгрунтованості та дотримання встановлених до неї вимог застосовувати положення правової норми, якщо ії застосування суперечить конституційним принципам права або може тягнути порушення права особи на звернення до суду за захистом своїх прав. Також суд не повинен допускати тлумачення закону, яке б несправедливо обмежувало зазначене право. Отже, на стадії відкриття провадження у справі суддя зобов'язаний діяти згідно зі встановленим порядком і керуватися «вищою цінністю» демократичної, соціальної 
та правової держави, тобто необхідністю забезпечити дотримання, реалізацію та захист прав людини.

Об'єктивним втіленням принципу верховенства права є принцип законності, який вимагає, щоб в адміністративному судочинстві на стадії відкриття провадження в адміністративній справі суддя керувався виключно нормами закону, в іншому разі необгрунтована відмова у відкритті провадження у справі, як і у разі залишення позову без руху або його повернення, є порушенням права особи на доступ до правосуддя.

А.А. Стародубцев пропонує при визначенні принципу законності включати «такі найбільш важливі ії ознаки: по-перше, законність є принципом діяльності всіх суб’єктів, залучених у правову діяльність; по-друге, головна їі суть полягає у безперечному та неухильному вживанні, виконанні й дотриманні легітимних норм права всіма суб'єктами права; по-третє, виховною і примусовою силою держави й лише в рамках компетенції повинне забезпечуватися точне, беззаперечне і неухильне здійснення лише легітимних норм права як із погляду форми, так і з погляду змісту; по-четверте, метою законності є охорона законних прав громадян, зміцнення суспільного та державного устрою» [6].

Реалізація принципу законності на стадії відкриття провадження означає те, що всі дії судді щодо прийняття та перевірки позовної заяви, а також винесення рішення повинні бути засновані на законі та з його практичної реалізації. Іншими словами, процесуальна діяльність суду на цій стадії повинна бути підпорядкована чіткій процесуальній процедурі, яка закріплена у нормах адміністративно-процесуального законодавства.

Із цього принципу випливає й наступний принцип неприпустимості зловживання процесуальними правами. 3 огляду на етимологію зловживання правами можна зробити висновок, що зловживати правами можуть особи, які безпосередньо наділені суб'єктивними правами, а зловживання правами виникає внаслідок неналежного їх використання [7, с. 73]. Так, відповідно до ч. 1 ст. 45 КАС України учасники судового процесу та їхні представники повинні добросовісно користуватися процесуальними правами, а зловживання процесуальними правами не допускається [8].

Якщо говорити про зловживання своїми процесуальними правами саме суддями адміністративного суду, то слід зазначити, що «таке зловживання не можна вважати судовою помилкою. 3 цього приводу є слушною думка О.К. Намясенко: «Зловживання, характеризується такими ознаками, як: 1) формальне здійснення (реалізація) суб' єктами їхніх юридичних прав чи обов' язків; 2) усвідомлення особою незаконності своїх дій, свідомий вихід за встановлені законом межі (наявність умислу); 3) заподіяння шкоди (збитку) інтересам суспільства чи інтересам іншої особи; 4) використання недозволених засобів і способів здійснення права та ін.» [9, с. 299-300], а отже, судді при розгляді справи по суті не повинні виходити за рамки своїх процесуальних прав, встановлених законом. В іншому разі таке зловживання є підставою для оскарження винесених суддею рішень, зокрема на стадії відкриття провадження у справі.

Кодексом адміністративного судочинства України гласність і відкритість адміністративного процесу визнано одним із основоположних принципів адміністративного судочинства. Рішення суду проголошується прилюдно, крім випадків, коли розгляд справи проводився у закритому судовому засіданні. Кожен має право на доступ до судових рішень у порядку, визначеному Законом. Судові рішення є відкритими та підлягають оприлюдненню в електронній формі не пізніше наступного дня після їх виготовлення і підписання [10]. Отже, важливим елементом стадії відкриття провадження у справі є гласність прийнятих рішень щодо подальшого руху справи. Прийняте рішення суду про відкриття провадження, відмова у відкриті провадження, 
залишення позову без розгляду або ії повернення повинно бути оприлюднено одразу після його виготовлення і підписання. Це гарантує право кожного отримувати інформацію про судові справи.

Варто також зазначити, що «гласність судочинства в Конституції асоціюється з повною фіксацією судового процесу технічними засобами, оскільки фіксація судового процесу технічними засобами розглядається як спосіб забезпечення гласності судочинства. Недотримання встановлених правил під час складання й оформлення суддею рішення позбавляє його процесуального значення» [11, с. 123].

Принцип обов'язковості судового рішення закріплено у ст. 129-1 Конституції України: «Суд ухвалює рішення іменем України. Судове рішення є обов'язковим до виконання» [4]. Йдеться про те, що з моменту проголошення судового рішення воно $\epsilon$ обов' язковим. «Однак статусу загальнообов' язковості, тобто обов' язковості не тільки для суду й осіб, що брали участь у справі, а й для усіх підприємств, установ, організацій, їхніх посадових (службових) осіб, фізичних і юридичних осіб воно набуває з моменту набрання ним законної сили» [2, с. 182]. Таким чином, рішення винесене судом на стадії відкриття провадження у справі є обов'язковим і підлягає виконанню. Незалежно від того, яке рішення було прийняте суддею, його обов'язковість є безперечною.

Принцип забезпечення апеляційного та касаційного оскарження рішення адміністративного суду полягає у гарантуванні усім особам, котрі беруть участь у справі, й особам, які не брали участь у процесі розгляду справи, у разі вирішення судом питання про їхні права й обов'язки права на апеляційне та касаційне оскарження рішень адміністративного суду. Відповідно до ст. 169, 170 та 294 КАС України рішення, що можуть бути винесені на стадії відкриття провадження у справі, можуть бути оскаржено в апеляційному порядку окремо від рішення суду. У ст. 328 КАС України зазначено право учасників справи, а також осіб, які не брали участі у справі, якщо суд вирішив питання про їхні права, свободи, інтереси та (або) обов'язки, оскаржити в касаційному порядку рішення суду першої інстанції після апелящійного перегляду справи [8].

Спеціальні принципи відкриття провадження у справі як стадії адміністративного судочинства - це такі основні положення, що розкривають суть здійснення даної стадії та відображають ії специфіку. До таких належать: 1) дотримання строків, встановлених для відкриття провадження; 2) обов'язковість розгляду позовної заяви на відповідність встановленим законом вимогам і вжиття всіх необхідних дій щодо ії перевірки; 3) принцип забезпечення доступу до суду.

Принцип дотримання строків, встановлених для відкриття провадження, виражений у ст. 119 КАС України [8], зокрема, суд має встановлювати розумні строки для вчинення процесуальних дій. Строк є розумним, якщо він передбачає час, достатній, з урахуванням обставин справи, для вчинення процесуальної дії, та відповідає завданню адміністративного судочинства. Перебіг процесуального строку починається з наступного дня після відповідної календарної дати або настання події, з якою пов' язано його початок. Якщо закінчення строку припадає на вихідний, святковий чи інший неробочий день, останнім днем строку є перший після нього робочий день. Останній день строку триває до двадцять четвертої години, але якщо в цей строк слід було вчинити процесуальну дію в суді, де робочий час закінчується раніше, строк закінчується в момент закінчення цього часу.

На стадії відкриття провадження у справі суддя повинен неухильно керуватися встановленими вимогами щодо строків розгляду позовної заяви та строків винесення рішення. Так, законом встановлено, що позовну заяву суд зобов' язаний розглянути протягом п'яти днів із дня надходження позовної заяви та винести одне із рішень - ухвалу 
про відмову у відкритті провадження у справі, про залишення позовної заяви без руху або про повернення їі, однак, якщо судом надано можливість усунути недоліки позову, строк обчислюється з дня закінчення строку на усунення недоліків.

Дотримання строків розгляду позовних вимог і винесення рішення на його підставі $\epsilon$ одним із головних завдань адміністративного судочинства - своєчасний судовий розгляд публічно-правового спору. Саме тому дотримання строків на стадії відкриття провадження у справі має таке важливе значення. Порушення строків саме на першій стадії судового процесу, по-перше, може негативно позначитися на подальшому розгляді справи по суті, по-друге, створить свідомо негативне ставлення учасників процесу до неупередженості та справедливості судочинства, по-третє, збільшить рівень недовіри до суду; й по-четверте, погано вплине на судову статистику.

Наступним принципом є обов'язковість розгляду позовної заяви на відповідність встановленим законом вимогам і вжиття всіх необхідних дій щодо ії перевірки. Із процесуального погляду, на суд покладається виняткова відповідальність у частині необхідності забезпечення максимально детального аналізу позову, а тому значення дій судді на цьому етапі відкриття провадження дуже важливе. Саме з моменту, коли суддею прийнято рішення про рух справи, настають правові наслідки, що відрізняються залежно від того, яке було прийнято рішення суддею - відкриття, відмова у відкритті, залишення позову без руху, повернення позову. Так, у разі відкриття провадження у справі головним правовим наслідком слід вважати виникнення адміністративного судочинства, а отже, адміністративно-процесуальних правовідносин. Якщо судом прийнято рішення про відмову у відкритті, провадження по справі не розпочинається, а отже, не може йтися про виникнення правовідносин, однак необгрунтована відмова у відкритті провадження у справі, як і у разі залишення позову без руху або його повернення, може спричинити також настання такого правового наслідку, як оскарження рішення суду, оскільки в такому разі «можна говорити про порушення права особи на доступ до правосуддя» [12, с. 134].

Принцип забезпечення доступу до суду. «Европейський суд із прав людини трактує доступ до правосуддя як одне з фундаментальних прав людини і громадянина, яке випливає зі змісту права на справедливий, незалежний безсторонній суд, утворений на підставі закону» [13, с. 220]. Це означає, що «адміністративний суд не має права створювати перешкоди для доступу в суд або в іншій спосіб позбавляти особу права на розгляд його справи» [14, с. 21], а отже, визначальним критерієм оцінки ефективності судової влади та правосуддя є доступність судового захисту прав, свобод та інтересів зацікавлених осіб.

Відмова суду у прийнятті позовних заяв, оформлених відповідно до чинного законодавства, є порушенням права на судовий захист, яке згідно зі ст. 64 Конституції України не може бути обмежене [15]. «Позов втілює право зацікавленої особи на відкриття провадження адміністративної справи в суді та судову діяльність на захист порушеного, невизнаного чи оскаржуваного права або інтересу, що охороняється законом» [16], i $є$ обов'язковою складовою частиною доступу до суду. У свою чергу, обов'язок національних судів обгрунтувати прийняті рішення також має принципове значення у реалізації особи права на доступ до суду. «В іншому разі вважатиметься, що було порушено право особи на доступ до суду. Так, у рішенні по справі «Проніна проти України» від 18 липня 2006 р. ССПЛ встановив порушення права особи на доступ до суду. Суд вказав, що п. 1 ст. 6 Конвенції зобов'язує національні суди надавати обгрунтування своїх рішень. Межі цього обов' язку можуть бути різними залежно від характеру рішення та положень законодавства, юридичних традицій викладення та формулювання рішень» [17, с. 13]. 
Саме тому на стадії відкриття провадження у справі так важливо дотримуватися цього принципу. При винесенні судом таких рішень, як відмова у відкритті провадження по справі, повернення заяви або залишення іiі без розгляду суддя повинен довести обгрунтованість своїх процесуальних дій, спираючись виключно на норми матеріального та процесуального права. Більш того, перевіряючи позовну заяву, суддя повинен надати особі можливість повною мірою реалізувати своє право на звернення шляхом усунення встановлених недоліків позову, надання додаткових документів, якщо такі не були додані до заяви, й тільки потім приймати остаточне рішення.

Ще одним засобом гарантування доступу особи до суду є право суду щодо зменшення розміру судових витрат або звільнення від їх оплати, або їх відстрочення та розстрочення. Так, відповідно до ст. 133 КАС України суд, враховуючи майновий стан сторони, може своєю ухвалою зменшити розмір належних до оплати судових витрат чи звільнити від їх оплати повністю або частково, чи відстрочити або розстрочити сплату судових витрат на визначений строк [8].

Висновки. Узагальнюючи викладене, слід зазначити, що принципи відкриття провадження в адміністративній справі є вихідними положеннями, на яких має грунтуватися процесуальна діяльність судді при прийнятті позовної заяви, іï розгляді та винесенні рішення про рух справи. Виокремлюємо загальні та спеціальні принципи відкриття провадження. Загальними є: 1) верховенство права; 2) законність; 3) гласність і відкритість судового процесу та його повне фіксування технічними засобами; 4) обов' язковість судового рішення; 5) забезпечення права на апеляційний перегляд справи; 6) забезпечення права на касаційне оскарження судового рішення у випадках, визначених законом. Спеціальними є: 1) дотримання строків, встановлених для відкриття провадження; 2) обов' язковість розгляду позовної заяви на відповідність встановленим законом вимогам і вжиття всіх необхідних дій щодо ії перевірки; 3) забезпечення доступу до суду. Визначені спеціальні принципи відрізняють цю стадію від інших елементів судового процесу. Ці принципи є визначальними, обов'язковими та непорушними приписами, які регламентують поведінку учасників стадії відкриття провадження у справі.

\section{Список використаних джерел:}

1. Бахрах Д.Н. Административное право : учебник. Москва : БЕК, 1996. 355 с.

2. Ковалів М.В., Стахура І.Б. Принципи адміністративного судочинства: поняття, зміст, система. Науковий вісник Лъвівського державного університету внутрішніх справ. Серія Юридична. 2014. Вип. 4. С. 174-184.

3. Ківалов С.В. Принципи адміністративного судочинства України як основоположні засади формування адміністративної юстиції. Актуальні проблеми держави $i$ права. 2005. Вип. 26. С. 5-18.

4. Конституція України : Закон України від 28 червня 1996 р. № 254к/96-ВР. Відомості Верховної Ради України. 1996. № 30. Ст. 141.

5. Корчинський О. Принципи адміністративного судочинства як основа захисту прав людини і громадянина. С. 151-156.

6. Стародубцев А.А. Принцип законності при здійсненні службової кар'єри в органах внутрішніх справ. Вісник Харківського національного університету внутрішнix cnpab. № 4. 2011. URL: http://archive.nbuv.gov.ua/portal/soc_gum/vkhnuvs/ 2011_54/54/44.pdf.

7. Зелінська Я.С. Зловживання процесуальними правами в адміністративному судочинстві: теоретичні та практичні аспекти. Юридичний бюлетенъ. 2020. № 15. C. 71-77. 
8. Кодекс адміністративного судочинства Україні : Закон України від 06 липня 2005 р. № 2747-IV. Відомості Верховної Ради Украӥни. 2005. № 35-36, № 37. Ст. 446.

9. Намясенко О.К. Деякі питання зловживання процесуальними правами у господарському судочинстві. Правове регулювання економіки. 2014. № 13. С. 294-305.

10. Про доступ до судових рішень : Закон України від 22 грудня 2005 р. № 3262-IV. Відомості Верховної Ради Украйни. 2006. № 15. Ст. 128.

11. Скрипченко В. Гласність та відкритість судового процесу в системі принципів адміністративного судочинства. Актуальні проблеми правознавства. 2019. № 4 (20). C. 121-125.

12. Помазанов А.В. Здійснення права на касаційне оскарження та відкриття касаційного провадження. Вісник Національного технічного університету України «Київський політехнічний інститут». Політологія. Соціологія. Право. 2018. № 2. С. 132-136.

13. Гнап Д.Д. Деякі аспекти реалій звернення до суду, створених новою редакцією Кодексу адміністративного судочинства України. Науковий вісник публічного та приватного права. 2018. Вип. 6. Т. 1. С. 219-223.

14. Гнап Д.Д. Право на судебную защиту в административном процессе Украины. Закон и жизнь (Legea si Viata). 2016. № 11. С. 21-23.

15. Рішення Конституційного Суду України у справі за конституційним зверненням громадян Проценко Р.М., Ярошенко П.П. та інших громадян щодо офіційного тлумачення ст. 55, 64, 124 Конституції України (справа за зверненнями жителів міста Жовті Води): від 25 грудня 1997 р., № 9-3п. URL: http:/ /www.ccu.gov.ua/doccatalog/ document?id=9052.

16. Бречко А.В. Адміністративний позов як форма захисту прав, свобод та інтересів у сфері публічно-правових відносин. Актуальні проблеми державного управління. 2009. № 2. C. 366-372. URL: http://nbuv.gov.ua/UJRN/apdy_2009_2_48.

17. Бойко В.Б. Забезпечення доступу до правосуддя на стадії пред'явлення позову. Форум права. 2016. № 2. C. 11-17. URL: http://nbuv.gov.ua/UJRN/FP_index. 